Published in final edited form as:

Vet Clin Pathol. 2012 December ; 41(4): 455-470. doi:10.1111/j.1939-165x.2012.00488.x.

\title{
Aquaporin-2 Regulation in Health and Disease
}

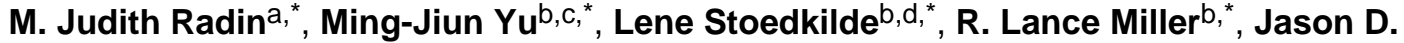 \\ Hoffert $^{\mathrm{b}}$, Jorgen Frokiaer ${ }^{\mathrm{d}}$, Trairak Pisitkun ${ }^{\mathrm{b}}$, and Mark A. Knepper ${ }^{\mathrm{b}}$ \\ aDepartment of Veterinary Biosciences, The Ohio State University, Columbus, $\mathrm{OH}$ \\ bEpithelial Systems Biology Laboratory, National Heart, Lung, and Blood Institute, National \\ Institutes of Health, Bethesda, Maryland, USA \\ Institute of Biochemistry and Molecular Biology, National Taiwan University College of Medicine, \\ Taipei, TAIWAN \\ ${ }^{\mathrm{d}}$ The Water and Salt Research Center, University of Aarhus, DK-8000 C, Denmark
}

\begin{abstract}
Aquaporin-2 (AQP2), the vasopressin-regulated water channel of the renal collecting duct, is dysregulated in numerous water balance disorders in humans and animals including those associated with polyuria (e.g. urinary tract obstruction, hypokalemia, inflammation, and lithium toxicity) and dilutional hyponatremia (e.g. SIADH). Normal regulation of AQP2 by vasopressin involves two independent regulatory mechanisms: 1) short-term regulation of AQP2 trafficking to and from the apical plasma membrane, and 2) long term regulation of the total abundance of the AQP2 protein in the cells. Most water balance disorders are the result of dysregulation of processes that regulate the total abundance of AQP2 in collecting duct cells. In general, the level of AQP2 in a collecting duct cell is determined by a balance between production via translation of AQP2 mRNA and removal via degradation and/or secretion into the urine in exosomes. AQP2 abundance increases in response to vasopressin chiefly due to increased translation subsequent to increases in AQP2 mRNA. Vasopressin-mediated regulation AQP2 gene transcription is poorly understood, although several transcription factor binding elements in the 5' flanking region of the AQP2 gene have been identified and candidate transcription factors corresponding to these element have been discovered in proteomics studies. Here we review progress in this area and discuss elements of vasopressin signaling in the collecting duct that may impinge on regulation of AQP2 in health and in the context of examples of polyuric diseases.
\end{abstract}

\section{Keywords}

Vasopressin; transcription; exosomes; polyuria; SIADH

\section{Introduction}

\begin{abstract}
Water balance disorders are frequent in both humans and in domestic animals. Abnormal water retention resulting in dilutional hyponatremia can be the consequence of neoplasms that secrete antidiuretic substances (syndrome of inappropriate antidiuretic hormone excess, SIADH), congestive heart failure, liver failure, and nephrotic syndrome [1]. In most cases, the water retention is caused by elevated circulating levels of vasopressin (antidiuretic
\end{abstract}

\footnotetext{
Correspondence: Mark A. Knepper, MD, PhD, National Institutes of Health, 10 CENTER DR, Bldg 10, Room 6N260, Bethesda, MD 20892-1603 USA, Phone: 301-496-3064 Fax: 301-402-1443, knep@ helix.nih.gov.

These authors contributed equally and should be regarded as $1^{\mathrm{st}}$ authors.
} 
hormone) via non-osmotic release. On the other side of the coin is abnormally low water retention resulting in polyuria [2]. Polyuria can result from a variety of disorders including central diabetes insipidus (failure of osmotic release of vasopressin from the posterior pituitary), and nephrogenic diabetes insipidus. Genetic forms of the latter can be the consequence of mutations in the V2 vasopressin receptor or aquaporin-2 (AQP2), the water channel that is regulated by vasopressin to control water excretion. Acquired forms of nephrogenic diabetes insipidus can result from hypercalcemia (e.g. in hyperparathyroidism or metastatic carcinomas), hypokalemia, sepsis (e.g. pyometra) or certain drugs such as lithium salts. In these syndromes, the kidneys display blunted antidiuretic responses to vasopressin. Vasopressin also plays an important role in polycystic kidney disease in humans and in certain breeds of domestic animals like the bull terrier dog [3] or the Persian cat [4]. Indeed, there are currently ongoing therapeutic trials of vasopressin receptor antagonists in the treatment of autosomal dominant polycystic kidney disease in humans [5].

The frequency of water balance disorders and abnormalities of the vasopressin/ osmoregulatory network point to the importance of understanding the normal physiological regulatory mechanisms underlying vasopressin action. Much of the antidiuretic action of vasopressin is associated with the regulation of the molecular water channel, aquaporin-2, in collecting duct cells. In what follows, we discuss this water channel and how it is regulated.

Of the 13 known mammalian aquaporins, eight (AQP1, -2, -3, -4, -6, -7, -8, -11) are expressed in the kidney [6]. AQP1-AQP4 play important roles in the mediation of water transport across the renal tubule [7],[6]. Aquaporin-1 (AQP1) is expressed at very high levels in the proximal tubule and thin descending limb of Henle [8] [9], correlating with the extremely high water permeability in these segments. In contrast, renal tubule epithelia with very low water permeability (thin ascending limb, thick ascending limb and distal convoluted tubules) do not appear to express aquaporins. The final portion of the renal tubule, the connecting tubules and collecting ducts have a variable water permeability that is controlled in response to the peptide hormone vasopressin [10]. This renal tubule segment expresses three aquaporins, aquaporin-2 (AQP2) in the apical plasma membrane [11] and aquaporin-3 and -4 (AQP3 and -4) in the basolateral plasma membrane [12] [13]. Although there is evidence for regulation of the basolateral water channels by vasopressin, it seems clear that the regulation of water permeability of the collecting duct epithelium is mediated chiefly through vasopressin's effects on AQP2.

Localization of AQP2 in the principal cells of the collecting duct is conserved across mammalian species including dogs, rats, mice, cynomolgus monkeys, cats, horses, sheep, dolphins and whales [14],[15],[16],[17],[18],[19]. In birds, AQP2 has been demonstrated in collecting ducts from both the mammalian-type (possessing loops of Henle) and reptiliantype (nonlooped) nephrons[20],[21],[22]. Expression of AQP2 and response to water deprivation appears greater in the medullary region, consistent with the conclusion that the mammalian-type nephrons are more sensitive to vasotocin, the avian equivalent of vasopressin, than are the reptilian-type nephrons.

There are at least two modes of water permeability regulation in the kidney collecting duct cells corresponding to two processes that control the amount of active AQP2 in the apical plasma membrane, the rate-limiting membrane for overall transepithelial osmotic water transport. The first mode is 'short-term regulation' occurring over a period of minutes as a result of the regulation of trafficking of AQP2-containing membrane vesicles to and from the apical plasma membrane in response to vasopressin [23]. The second mode is 'long-term regulation' occurring over a period of hours to days as a result of regulation of whole cell AQP2 abundance by vasopressin [24],[25],[26]. Here we focus on long-term regulation of 
AQP2 abundance in the renal collecting duct, a process that appears to be dysregulated in a large number of clinical conditions characterized by disturbances in water balance.

\section{Normal Regulation of AQP2 Protein Abundance in Renal Collecting Duct Possible mechanisms involved in long-term regulation of AQP2 protein abundance}

It is well established that vasopressin markedly increases AQP2 abundance in the renal collecting duct of rodents [24] [25] [26]. Typically, changes in AQP2 protein abundance in the range 4-10 fold are seen in these studies after long-term increases in circulating vasopressin levels. Brattleboro rats, which lack endogenous vasopressin (central diabetes insipidus), have minimal AQP2 mRNA and protein. When infused with vasopressin, the Brattleboro rats respond to vasopressin with increase in AQP2 mRNA and protein levels [26],[27],[28]. Thus, vasopressin is necessary for the long-term maintenance of $A Q P 2$ gene expression in the collecting ducts.

In Brattleboro rats that were infused with vasopressin via osmotic minipumps, absolute quantification of AQP2 by ELISA in microdissected inner medullary collecting ducts showed 1-day lag in AQP2 increase with a maximal increase to 5 times the control valuse in 5 days [28]. A different study in primary cultures of inner medullary collecting ducts from rats suggested that AQP2 abundance can increase much faster, showing an approxiamtely $50 \%$ increase in AQP2 band density on immunoblots within 30 minutes of exposure to arginine vasopressin without an apparent change in AQP2 mRNA [29]. In contrast, 30 minute exposure of rat inner medullary collecting duct (IMCD) suspensions [30] or cultured mouse collecting duct cells (mpkCCD) [31] did not reveal any measurable change in AQP2 abundance.

To explain the long-term increase in AQP2 abundance brought about by vasopressin, it is useful to begin by enumerating possible mechanisms by which this regulation could occur (Figure 1). The amount of AQP2 in a given connecting tubule cell, collecting duct principal cell or IMCD cell at steady state represents a balance between production of AQP2 by translation and removal from the cell by either degradation or exosomal secretion. In the following sections, we discuss potential roles for each.

\section{AQP2 removal by exosome excretion}

The secretion of intact AQP2 into the urine was first identified by Kanno et al [32] and later the mechanism of secretion was identified to be via exosome secretion into the urine by Pisitkun and colleagues [33]. Exosomes are the internal vesicles of multivesicular bodies (late endosomes) that are delivered to the lumen of the renal tubule by every cell type facing the urinary space [34]. It has been shown that a large fraction of AQP2 endocytosed from the cell surface is delivered to multivesicular bodies in collecting duct cells [23]. The proteome of urinary exosomes has been elucidated [33] [35] and is publicly available in an online database (http://dir.nhlbi.nih.gov/papers/lkem/exosome/). Multiple publications have reported measurement of urinary AQP2 excretion as an indicator of the state of the kidney with regard to AQP2 regulation [32],[36],[37],[38],[39],[14],[40]. The results of these studies are consistent with the conclusion that vasopressin increases AQP2 excretion [32], [36],[37],[38],[39],[14], suggesting that the increase in AQP2 in the kidney is not due to an effect of vasopressin to decrease its elimination via exosomal secretion.

It should be emphasized that measurements of the excretion rate of AQP2 are difficult to carry out and to interpret. This is in part due to the fact that the rate of urinary excretion of AQP2 at steady state is the difference between the rate of production by translation and the rate of cellular degradation of AQP2 (Figure 1). Thus, under steady-state conditions, an increase in urinary AQP2 excretion could reflect either an increase in synthesis or a decrease 
in degradation. Both of these processes would be expected to be associated with increased AQP2 abundance in the cell, which could be reflective of an increase in vasopressin action. However, if steady-state conditions are not established, an increase in urinary AQP2 excretion could merely be a reflection of a transient increase in AQP2 endocytosis, which would indicate a decrease in vasopressin action in the collecting duct. Thus, analysis of urinary AQP2 excretion rate is interpretable only if a steady state is established, which may not always be true in spot urine samples.

\section{AQP2 elimination from collecting duct cells by intracellular degradation}

The rate of AQP2 protein degradation can theoretically be altered to account for vasopressin-mediated increases in cellular AQP2 abundance. AQP2 degradation can presumably occur via incorporation into lysosomes or via proteasomal degradation. Proteins are marked for both via ubiquitination. Mono- or oligo-ubiquintination targets proteins for lysosomal degradation, while multi-ubiquitination targets proteins for proteasomal degradation. Recently, Deen et al demonstrated that AQP2 can be oligo-ubiquitinated at lysine-270, which is the second from last amino acid at the $\mathrm{COOH}$-terminus [41]. We have recently used proteomics techniques to measure the half life of AQP2 in cultured collecting duct cells (mpkCCD cell line), showing that at steady state, vasopressin significantly increases the half life of the AQP2 protein from 10 to 14 hours [42]. This magnitude of increase, however, cannot explain the 4-10 fold increase in total AQP2 proteins seen in these cells in response to vasopressin [31].

\section{AQP2 production (translation) in the collecting duct cell}

Changes in the rate of AQP2 production in collecting duct cells can theoretically be due to changes in the abundance of AQP2 mRNA or to direct regulation of translation, e.g. in the endoplasmic reticulum stress response [43]. In rat collecting ducts, vasopressin produces a clear increase in AQP2 mRNA abundance [44] [45], suggesting that increased AQP2 translation, if it occurs, is due at least in part to increased AQP2 mRNA levels. In cultured mpkCCD cells, among the 188 proteins that underwent significant vasopressin-induced changes in abundance based on quantitative mass spectrometry studies, a more than a third had no change in the corresponding mRNA species, suggesting translational or posttranslational regulation of protein abundance. The mRNA changes presumably were due to some level of transcriptional control in response to vasopressin, although regulation of mRNA stability cannot be ruled out [46]. In the same study, AQP2 manifested increases in both mRNA and protein, however, making it uncertain as to whether translation of AQP2 is directly regulated by vasopressin.

It is important to note that AQP2 mRNA levels may not necessarily reflect amount of AQP2 mRNA available for translation because of regulated sequestration of mRNAs [47], a process which has not been investigated with regard to long-term regulation of AQP2 abundance. The total abundance of AQP2 mRNA can theoretically change as a result of changes in the degradation rate or changes in the transcription rate. There has been recent progress in mechanisms involved in regulation of mRNA degradation via so-called microRNAs (miRNAs) [48], which are transcribed from non-protein-coding genes. miRNAs bind to specialized motifs in the 3'-untranslated regions of mRNA transcripts and target them for degradation via the RISC (RNA-induced silencing complex) mechanism. Although several potential miRNA binding motifs can be identified in the 3'-untranslated region of the AQP2 transcript (unpublished observations) there is as yet no evidence that AQP2 mRNA abundance is regulated by specific miRNAs. 


\section{Regulation of AQP2 transcription}

Despite the possibilities described above for regulation of AQP2 protein abundance by vasopressin, most workers have assumed, probably correctly, that the regulation of AQP2 protein abundance is largely due to regulation of transcription of the AQP2 gene. One strategy to investigate transcriptional regulation is to analyze 5'-flanking regions of a gene for cis-element motifs to which transcription factors bind and regulate gene transcription. The isolation of the AQP2 gene by Sasaki's group provided a starting point for this analysis [49]. Through analysis of the 5'-flanking regions of AQP2 from several species, conserved putative binding motifs for several transcription factor families have been identified [50], [31],[51] including a cAMP-response element (CRE), several Ets sites, a GATA site, an Sp1 site, a Forkhead box, a Hox site, an RXR site, and an NFAT site. Proteomic studies of nuclei isolated from inner medullary collecting duct cells have identified transcription factors that can potentially bind these sites [51],[52]. Further proteomics studies have been conducted to identify transcription factors that undergo vasopressin-mediated translocation to the nucleus [52], providing evidence for increased nuclear abundance of JunB, Elf3, Gatad2b in response to vasopressin. Some of the identified cis-elements have undergone further study using site-directed mutagenesis and promotor-reporter assays as described in the following.

CRE-Studies using deletion or site-specific mutagenesis of the cyclic AMP response element (CRE) site confirmed the importance of this cis element in vasopressin-stimulated AQP2 transcription [53],[54],[55]. Although the transcription factor that most frequently binds to this site, CREB, is expressed in collecting duct cells, it is presently unclear whether CREB itself, or one of several CREB-like transcription factors may be involved in AQP2 transcriptional regulation.

GATA-Using DNase I footprint analysis, Rai et al found a protected GATA element just downstream of the CRE site in the AQP2 5'-flanking region using rat liver nuclear extract [50]. Deletion and mutation of this cis-element abolished protein-DNA binding and increased promoter activity in hetaptocyte Ac2F cells [50] and mouse outer medullary collecting duct cells [56], suggesting a negative regulatory role of the GATA element. In a later experiment, over-expressing GATA-3 transcription factor increased GATA element activity in mouse outer medullary collecting duct cells [57]. These data suggest that the GATA element may be part of a complex non-linear regulatory network. Gatad $2 b$ was found to translocate into the nucleus in response to vasopressin in cultured mpkCCD cells derived from mouse collecting duct [52].

Ets-We have investigated the potential role of the Ets cis-elements in the vasopressin response. Vasopressin was shown to increase AQP2 transactivation by three Ets-family transcription factors (Elf3, Elf5 and Ehf) in promotor-reporter studies [31]. In mouse mpkCCD cells, Elf3 was found to translocate into the nucleus in response to vasopressin [52].

Nfat-The nuclear factor of activated T cells (NFAT) family of transcription factors was found to be involved in tonicity-regulated $A Q P 2$ gene expression in pmkCCD cells [58]. The cells respond to hypertonic medium with increases in both AQP2 mRNA and protein levels [58]. There are five members in the NFAT family including NFATc1-4 and NFAT5 also known as tonicity-responsive enhancer binding protein (TonEBP). Both NFATc and TonEBP were found to regulate $A Q P 2$ gene expression in mpkCCD cells. The increases in AQP2 mRNA and protein abundance were reduced when TonEBP expression was reduced via small interfering RNA technology, or when a dominant negative TonEBP mutant was expressed, indicating a role of TonEBP in tonicity-regulated $A Q P 2$ gene expression. In other studies, NFATc1 was found to enhance AQP2 promoter activity [59]. Some skepticism 
regarding the role of tonicity changes in the regulation of $A Q P 2$ gene expression is warranted since $\mathrm{AQP} 2$ protein abundance was not altered by measures that change the osmolality of the renal medullary interstitium in rats [60]. Furthermore in the terminal IMCD, increases in medullary tonicity brought about by water restriction in rats did not produce a translocation of TonEBP into the nucleus despite clear nuclear translocation in neighboring loop of Henle cells [61].

Further studies are needed 1) to verify binding interactions between candidate transcription factors and the 5'-flanking region of the AQP2 gene; 2) to determine whether these binding interactions are regulated by vasopressin; and 3) to determine whether each of the candidate transcription factors are essential to vasopressin-mediated regulation of AQP2 abundance.

\section{Vasopressin signaling in the renal collecting duct}

The answer to the question of how vasopressin regulates AQP2 abundance in the renal collecting duct depends on knowledge of vasopressin signaling pathways. Vasopressin signaling in connecting tubules and collecting ducts involves a complex network of signaling components [30]. Vasopressin binds to $\mathrm{V}_{2}$ vasopressin receptors in the basolateral plasma membranes of connecting tubules and collecting ducts. This is a G-protein coupled receptor that signals by activating two adenylyl cyclases (AC3 and AC6) [62] through Gsa activation. The consequence is a rise in cyclic AMP in the collecting duct cells. If isolated perfused collecting ducts are exposed to cyclic AMP analogs, the water permeability increases following a time course similar to that seen with vasopressin [63] [64] implying that the signaling processes that are essential for the water permeability response are downstream from cyclic AMP. A vasopressin-induced rise in intracellular cyclic AMP is associated with activation of protein kinase A (PKA) by binding to the inhibitory regulatory subunits of PKA and disinhibiting the catalytic subunit.

In addition to a rise in cyclic AMP, vasopressin evokes a rise in intracellular $\mathrm{Ca}^{2+}$ concentration in collecting duct cells [65]. The $\mathrm{Ca}^{2+}$ mobilization can also be reproduced by addition of exogenous cAMP. High resolution techniques capable of imaging individual collecting duct cells have demonstrated that the vasopressin-induced rise in intracellular $\mathrm{Ca}^{2+}$ consists of aperiodic calcium spikes that are independent of $\mathrm{Ca}^{2+}$ changes in neighboring cells [66],[30]. The rise in intracellular $\mathrm{Ca}^{2+}$ is associated with an increase in phosphorylation of myosin regulatory light chain [67], via a $\mathrm{Ca}^{2+}$-calmodulin mediated activation of myosin light chain kinase. $\mathrm{Ca}^{2+}$-calmodulin also enhances cyclic AMP production by stimulating AC3 [62].

Vasopressin also causes a PI-3K dependent activation of Akt (protein kinase B) in the IMCD, as well as an inhibition of the ERK1/2 MAP kinase pathway [30]. The roles of these pathways in the long-term regulation of AQP2 are not known, although they are well documented to regulate AQP2 phosphorylation and presumably trafficking [68],[30],[69].

Phosphoproteomic approaches are being used to identify the protein kinases involved in regulation of aquaporin-2 abundance in collecting duct cells [68], [70], [69]. In general, these studies have demonstrated that basophilic kinases (especially AGC and calmodulinregulated kinases) have increased activity in response to vasopressin, while proline-directed kinases (MAP kinases and cyclin-dependent kinases) manifest decreased activity. Of the 518 protein kinases in mammalian genomes, approximately 200 are expressed in the renal inner medullary collecting duct [71]. Sorting out what kinases phosphorylate what proteins in response to vasopressin is a major point of focus for future studies.

Understanding vasopressin signaling mechanisms in the collecting duct may provide information that is critical to developing better therapeutic approaches to cystic diseases of 
the kidney, especially autosomal dominant polycystic kidney disease (ADPKD). There is extensive evidence that vasopressin accelerates the rate of growth of cysts in ADPKD [72] . Polycystic kidney disease has been reported in most veterinary species. It is best characterized in Bull Terrier dogs [3],[73] and Persian cats [4],[74], which display autosomal dominant inheritance linked to the PDK1 gene, similar to ADPKD in humans. Cysts in ADPKD arise from collecting duct cells and contain V2 receptors [75],[76]. Humans and several animal models with PKD have increased circulating vasopressin which has been suggested to contribute to the progression of cyst development and renal functional decline. Vasopressin binding to V2 receptors may drive cyst growth by increasing intracellular cAMP which will increase both $\mathrm{Cl}^{-}$dependent fluid secretion and ERK-driven proliferation of cyst lining epithelial cells [77]. Based on observations in both humans and rodent models, treatment with vasopressin antagonists offer great promise as a means of slowing the rate of development of cysts [5],[76],[78].

\section{Dysregulation of AQP2 in Disease}

Several clinically important water balance disorders have been shown to be associated with dysregulation of AQP2, chiefly the long-term regulation of AQP2 abundance. These include polyuric syndromes, ECF volume-expanded states, and the syndrome of inappropriate antidiuresis (SIADH) (see Nielsen et al. for complete review) [6]. Here we limit our discussion to polyuric syndromes and SIADH. An excellent review on the role of AQP2 in ECF volume-expanded states has been published by Schrier and colleagues [79].

\section{AQP2 in polyuric syndromes}

The amount of AQP2 in collecting duct cells has been shown to be decreased in a variety of polyuric disorders as demonstrated in many animal studies [6] . Among the earliest to be studied was central diabetes insipidus (CDI). In general, CDI is associated with low or absent circulating vasopressin due to a defect in some aspect of the production or secretion of vasopressin in the hypothalamus and posterior pituitary gland. An important animal model for CDI is the Brattleboro rat, which lacks circulating vasopressin owing to a mutation in the vasopressin-neurophysin gene. These animals manifest extremely low levels of AQP2 in their kidneys [26]. Infusion of vasopressin can restore kidney AQP2 protein levels to normal [26], but it can take as long as 7 days of vasopressin replacement to reach the levels seen in wild-type rats [28]. The slow response complicates testing for CDI in humans, since full restoration of concentrating capacity in response to a single dose of vasopressin is unlikely. In effect, animals and humans with CDI always have an element of nephrogenic diabetes insipidus (NDI) due to suppression of renal AQP2 levels.

Diagnosis of CDI in veterinary species is typically based on failure to concentrate urine during a water deprivation test followed by restoration of concentrating ability in response to desmopressin. As in humans and rats, it may take several days to observe a response to desmopressin in veterinary species, presumably due to down-regulation of AQP2 expression [80],[81]. In some cases, vasopressin response to infusion with hypertonic saline has been used in diagnosis. Congenital or inherited CDI is presumed based on juvenile onset of clinical signs; however, genetic evaluation is lacking in most veterinary cases. In dogs, CDI may be idiopathic [82] or the consequence of head trauma [83],[84] or neoplasia affecting the pituitary [82],[85],[86],[87],[88],[89],[90],[91]. In older dogs, CDI due to primary pituitary tumors may be complicated by accompanying hyperadrenocorticism. CDI also may be a consequence of surgical resection of the pituitary tumor with the postsurgical risk for permanent CDI related to the size of the tumor [88] [87]. Other CNS tumors that have been implicated in the development of CDI in the dog include lymphoma [90] and metastatic carcinoma [91]. Congenital CDI in dogs has been rarely reported [82],[92],[40]. The 
majority of the reported cases of CDI in cats were the result of head trauma [93],[94],[95], [96] or were idiopathic[97],[98],[99],[100] with rare reports of congenital onset [101] or secondary to neoplasia [102].

In the horse, CDI may be idiopathic [103] or secondary to encephalitis [104]. Polyuria is seen in about $30 \%$ of horses with pituitary pars intermedia dysfunction and is likely a consequence of both loss of vasopressin production secondary to neuronal degeneration and hypercortisolism [105]. Congenital cases in the horse have been reported but are rare [106]. There are sporadic case reports of CDI in cattle and sheep; one of a 7-mo-old heifer with hydrocephalus that exhibited clinical signs compatible with CDI [107], a transient case in an older cow with metabolic disease [108] and a 7-mo-old ram with degeneration of the pituitary [109].

Compulsive water drinking is another cause of polyuria due to CNS abnormalities. In humans, this is seen most often in psychiatric patients. Primary polydipsia of behavioral or psychogenic origin have also been recognized in dogs and horses. Lack of exercise, boredom, or stress may fuel compulsive drinking in dogs [110]. Urine concentrating ability in response to water deprivation is intact, and even under conditions of free access to water, urine specific gravity and osmolality may fluctuate from dilute to concentrated over a $24 \mathrm{hr}$ period [111], [112]. There is considerable variation in baseline serum sodium concentration, baseline circulating vasopressin, and vasopressin response to hypertonic saline infusion [40], [111]. Systemic diseases that may trigger primary polydipsia in dogs include hepatic disease [113] and gastrointestinal disease [114]. Psychogenic polydipsia is seen in horses confined by stabling and is attributed to boredom [115],[116], although other factors such as hot and humid conditions, diet or changes in surroundings have been cited as contributing factors [81]. Rarely psychogenic excess salt consumption precipitates the polydipsia in horses [117]. In food animals, polydipsia in response to excess salt intake usually results from improper formulation of feed or access to high salt containing forage which, if extreme, may result in salt toxicity [118]. While cats may consume water as part of play, overt psychogenic polydipsia is not documented [110]. Naturally occurring lesions in the thirst centers of the brain as a cause of primary polydipsia have not been documented in domestic animals. With compulsive water drinking, excessive water intake keeps circulating vasopressin levels very low, resulting presumably in suppressed AQP2 levels in the kidney. As with CDI, vasopressin levels must be restored for several days to produce normal AQP2 levels in the kidney and normal rates of urine flow.

Another form of overdrinking, prevalent in humans, is so-called "cultural overhydration", embodied in the modern edict to drink eight 8-ounce glasses of water per day, independent of thirst [119] . Excessive drinking of coffee and other beverages can also result in chronic suppression of circulating vasopressin levels. (The effect of coffee is related to its water content, rather than caffeine itself. Caffeine was found not to have any demonstrable effect on urinary concentrating ability or water excretion when water intake was held constant [authors' unpublished results]). As with compulsive water drinking, chronically exaggerated water drinking behavior can suppress circulating vasopressin and lower renal AQP2 levels [60], thus making it impossible to conserve water under circumstances that demand it [120], such as strenuous exercise with sweating. Thus, overdrinking can also lead to impairment of athletic performance in humans [121] and presumably in animals.

Nephrogenic diabetes insipidus (NDI) is a syndrome of varied etiology that is associated with a failure of the kidney to conserve water. Heritable NDIs are relatively rare genetic disorders associated with mutations in specific genes associated with collecting duct function. Most common is $\mathrm{X}$-linked NDI due to mutations in the vasopressin $\mathrm{V}_{2}$ receptor that is normally expressed in the collecting duct and is crucial to renal water conservation 
[122]. Primary nephrogenic diabetes insipidus has been documented in males from family of husky dogs and was characterized by decreased binding affinity of the vasopressin receptor, suggesting a similarity to the human X-linked disease [123]. Congenital, possibly X-linked NDI also has been reported in the male offspring of a Thoroughbred mare [124]. In humans, most cases of non-X-linked NDI appear to be associated with mutations in the AQP2 gene [125]. These can either be autosomal dominant or recessive, depending in part on the site of the mutation in the AQP2 molecule. Spontaneous autosomal recessive NDI occurred in a line of White Leghorn chickens [126] and Japanese quail [127]; however, the underlying mutations have not been elucidated.

The most common forms of NDI are the so-called 'acquired' NDI syndromes. Acquired NDI is seen in association with sustained ureteral obstruction, sustained hypokalemia, sustainedlithium intake, or sustained inflammation. Each of these syndromes is associated with depletion of AQP2 protein from the kidney, i.e. an impairment of the long-term regulatory process discussed above [128] [129] [130]. However, in general, the molecular mechanisms of the depletion are poorly understood and any of the mechanisms shown in Figure 1 could play roles. Because of the importance of these acquired NDI syndromes, they are discussed in detail in the following.

\section{Ureteral obstruction-induced NDI}

Urinary tract obstruction is a common condition which may be caused by numerous diseases. Characteristically, urinary tract obstruction is associated with changes in renal water handling and, after release of ureteral obstruction, the kidney has a reduced ability to concentrate urine and hence polyuria is observed [129],[131],[132]. Twenty-four hours of bilateral ureteral obstruction (BUO) or unilateral obstruction (UUO) in rats resulted in a marked decrease in AQP2 abundance in the native IMCD [129],[131]. Seven days after release of BUO the animals still had a urinary concentrating defect and AQP2 levels were only one-half of that seen in the controls [129]. In UUO a similar downregulation of AQP2 protein levels in the obstructed kidney has been demonstrated. This reduction was selective for the obstructed kidney and correlated with a decrease in the AQP2 mRNA abundance, suggesting that the observed decrease in AQP2 protein abundance is due to regulation at the transcriptional level (or regulation of mRNA degradation) and that non-systemic local factors play a role in AQP2 down-regulation [131]. In multiple studies we have demonstrated that, despite this markedly reduced abundance of AQP2, there is maintained AQP2 trafficking to the apical plasma membrane suggesting that the intracellular signaling mechanism responsible for AQP2 translocation is still functional after obstruction [129], [131],[133]. Kim et alhave demonstrated reduced cAMP generation in response to vasopressin in kidney tissue in responseto BUO demonstrating that the vasopressin receptor or its coupling to adenylyl cyclase is affected by obstruction [134]. Interestingly, it was recently demonstrated that treatment of BUO rats with candesartan (an angiotensin receptor blocker) prevented the reductionin AQP2 expression levels [135], suggesting that increased intrarenal angiotensin II generationin the obstructed kidneys could possibly play a role perhaps by inhibiting vasopressin signaling. Importantly, it has also been demonstrated that treatment with a specific cyclooxygenase-2 (COX-2) inhibitor prevented downregulation of $\mathrm{AQP} 2$ and reduced the postobstructive polyuria indicating that COX-2 may be an important factor contributing to the impaired renal water and sodium handling in response to BUO [136],[137].

\section{Lithium induced NDI}

Human patients with bipolar disorder are often treated with lithium salts and 30-40\% of these patients develop drug-induced NDI followed by chronic kidney disease if sustained [138]. In dogs, prolonged exposure to lithium as a therapeutic agent used to stimulate 
hematopoiesis or in contaminated water resulted in polyuria and production of hyposthenuric urine which resolved upon withdrawal [139],[140]. In experimental studies, rats treated with lithium for 25 days experienced a 95\% reduction in AQP2 protein levels paralleled by a progressive development of severe polyuria [128]. The urine from lithiumtreated rats did not contain $\mathrm{AQP} 2$, therefore excretion of $\mathrm{AQP} 2$ into the urine is not responsible for the reduced AQP2 protein abundance seen in the kidney [141]. AQP2 mRNA abundance was significantly reduced after 10 days of lithium treatment suggesting that this reduction plays a role in the reduced AQP2 protein levels [142]. Return to a lithium free diet for 7 days was associated with only a moderate increase in urine osmolality and AQP2 levels [128].

It has been proposed that the polyuria seen in lithium-treated animals was a consequence of a decreased production of cyclic AMP possibly by direct inhibition of adenylate cyclase [143] [6]. However, it was recently shown that both in mpkCCD cells and in vivo, the lithium-induced downregulation of AQP2 mRNA and protein levels occurred independent of adenylyl cyclase activity and vasopressin-induced cyclic AMP levels [144]. High luminal calcium concentration reduces water permeability in rat inner medullary collecting ducts via a mechanism involving calcium sensing receptor, CaSR [145]. In the mpkCCD-c14 cells, Bustamante et al further showed that CaSR attenuates vasopressin-induced AQP2 protein abundance via calmodulin-dependent pathway [146].

Also, in rats, lithium-induced polyuria can be reduced by cyclooxygenase-inhibiting nonsteroidal anti-inflammatory drugs (NSAID), and it has been suggested that COX-2 is the key target. Lithium was both in vitro and in vivo shown to inhibit glycogen synthase kinase- $3 \beta$ (GSK3 $\beta$ ) resulting in increased COX-2 abundance and promotion of COX-2 dependent polyuria [147]. In a recent publication using a proteomics approach, 77different proteins within the IMCD were affected, eitherdirectly or indirectly, by lithium treatment [148]. The proteins identifiedhave a variety of functions, including signal transduction,regulation of gene expression, cytoskeletal organization, cellularreorganization, apoptosis, and cell proliferation. A numberof these proteins are ubiquitously expressed, such as GSK3 $\beta$. These studies clearly demonstrate that the cellulareffects of lithium treatment are broad and complex, and as sucha single pathway leading to reduced AQP2 abundance and subsequentpolyuria is unlikely [147],[148].

\section{Hypokalemia-induced NDI}

Another clinically important cause of NDI is the electrolyte disturbance hypokalemia. The condition arises in connection with diuretic therapy and is associated with polyuria though not so marked as in lithium treatment. Studies in animals done before the discovery of aquaporin-2 have demonstrated that prolonged potassium depletion results in a defect in urinary concentrating ability [149], [150],[151],[152]. The defect appear to be at least in part due to central mechanisms, either primary polydipsia [149] or blunted vasopressin secretion [152], or both.

Rats treated with a potassium-deficient diet for 11 days experienced a significant downregulation of AQP2 abundance in inner medulla and cortex; return to normal diet led to normalization of AQP2 levels and of the urinary concentrating capacity [153]. Time course studies done by Amlal et al [154] revealed that urinary concentrating ability was impaired with as little as $12 \mathrm{~h}$ of potassium deprivation. AQP2 was downregulated in the cortex after only $12 \mathrm{~h}$ of deprivation, in outer medulla after $24 \mathrm{~h}$ of deprivation and correlated with the early urinary concentrating defect. Moreover the study showed that AQP2 mRNA abundance in the outer medulla and cortex was decreased after $12 \mathrm{~h}$ of potassium deprivation and it was further decreased after 24 hours of depletion [154]. 
Studies in mice in which the gene for the thiazide-sensitive $\mathrm{NaCl}$ cotransporter was knocked out (a model for chronic thiazide treatment) also showed that hypokalemia can occur in response to restriction of potassium intake. They showed that the resulting polyuria is associated with decreased abundance of the aquaporin-2 protein in the kidney and does not necessarily require prior polydipsia.

\section{NDI with inflammation}

Polyuria and impaired renal concentrating ability is a common finding in dogs with pyometra [155]. Polyuria is reported less frequently in cats with pyometra (only $9 \%$ of cats in one study) [156] but whether this is a species difference or a reflection of the difficulty in detecting polyuria by owners is uncertain. Secretion of vasopressin in response to hypertonic saline by dogs with pyometra is similar to healthy dogs, while urinary concentrating ability in response to desmopressin is blunted [157]. Renal sensitivity to vasopressin and concentrating ability usually resolves in weeks to months following ovariohistorectomy, although some dogs may go on to develop progressive chronic renal failure [158],[159]. Activation of inflammatory cytokine signaling pathways may explain the concentrating defect seen with pyometra. Injection of rats with endotoxin rapidly decreases expression of vasopressin V2 receptors in the renal medulla and subsequently decreases AQP2 protein expression [160]. Incubation of kidney slices with interleukin-1 $\beta$ decreases vasopressin binding [160], while enhanced NF- $\mathrm{KB}$ signaling is a negative regulator of AQP2 gene expression [161]. Inhibition of NF- $\kappa B$ signaling ameliorates sepsis-induced downregulation of vasopressin V2 receptors and AQP2 in mice [162]. While infection with E. coli and Kebsiella species is common in canine pyometra, supporting a role of endotoxin, renal dysfunction with polyuria is not exclusive to dogs infected with gram negative bacteria [163].

\section{Aquaporin-2 in the syndrome of inappropriate antidiuresis (SIADH)}

In SIADH, inappropriately high levels of circulating vasopressin result in water retention and hyponatremia. In human patients, this is most often seen with neoplastic diseases, especially lung cancer. In dogs, SIADH has been seen with hydrocephalus [164], amebic meningoencephalitis [165], heartworm disease [166], hypothalamic meningeal sarcoma [167], and idiopathic etiologies [168], [169]. SIADH has been reported 2 cats; one with liver disease [170] and one subsequent to vinblastine overdose [171].

SIADH is due to constitutively high circulating levels of vasopressin or other antidiuretic substances. Rat models of SIADH have demonstrated that kidney AQP2 protein and mRNA levels are increased in this syndrome [172] [173] [45]. The degree of hyponatremia appears to be limited by a process that counters the water-retaining action of vasopressin, viz., the process of 'vasopressin escape'. Studies of the vasopressin escape process in rats have revealed that the escape is due to a suppression of AQP2 mRNA and protein levels by a process that affects AQP2 transcription rate [45]. The process is associated with a fall in intracellular cyclic AMP levels due to a decrease in coupling between the vasopressin V2 receptor and the two adenylyl cyclases that it activates [174] and is associated with a downregulation of vasopressin $\mathrm{V}_{2}$ receptors [173].

\section{Conclusion/Summary}

AQP2 water channels mediate osmotic water transport across the apical membranes of principal cells in the renal collecting duct. These water channels are regulated in response to binding of vasopressin to $\mathrm{V} 2$ receptors in the basolateral plasma membrane. Vasopressin triggers trafficking of intracellular vesicles containing AQP2 toward the apical plasma membrane where they fuse, thereby increasing water permeability. This allows reabsorption 
of water from the urine and provides a relatively rapid response (in 5-15 minutes) to alterations in plasma osmolality. Longer term regulation of water balance ( $>24$ hours) involves changes in transcription and translation of the AQP2 gene in response to vasopressin to regulate the abundance of AQP2 in collecting duct cells. Disorders of water balance are common in humans and veterinary species. Extensive studies in rodent models have established that most of these water balance syndromes result from abnormalities in the regulation of AQP2 gene expression, i.e. in the long-term response to vasopressin. While genetic defects that disrupt the vasopressin/AQP2 pathway have been described in humans and animals, acquired central and nephrogenic processes are more common causes of polyuric diseases. Understanding of the regulation and production of AQP2 both informs our understanding of mechanisms underlying chronic abnormalities of water balance and may point the way to more specific therapeutic interventions. Beyond the use of vasopressin replacement therapy such as desmopressin, interventions may include use of specific COX inhibitors or vasopressin antagonists.

\section{References}

1. DiBartola SP. Hyponatremia. Vet Clin North Am Small Anim Pract. 1998; 28:515-532. [PubMed: 9597712]

2. Nichols R. Polyuria and polydipsia. Diagnostic approach and problems associated with patient evaluation. Vet Clin North Am Small Anim Pract. 2001; 31:833-844. v. [PubMed: 11570128]

3. O'Leary CA, Duffy D, Biros I, Corley S. Linkage confirms canine pkd1 orthologue as a candidate for bull terrier polycystic kidney disease. Anim Genet. 2009; 40:543-546. [PubMed: 19397527]

4. Young AE, Biller DS, Herrgesell EJ, Roberts HR, Lyons LA. Feline polycystic kidney disease is linked to the PKD1 region. Mamm Genome. 2005; 16:59-65. [PubMed: 15674734]

5. Torres VE, Meijer E, Bae KT, Chapman AB, Devuyst O, Gansevoort RT, Grantham JJ, Higashihara E, Perrone RD, Krasa HB, Ouyang JJ, Czerwiec FS. Rationale and design of the TEMPO (Tolvaptan Efficacy and Safety in Management of Autosomal Dominant Polycystic Kidney Disease and its Outcomes) 3-4 Study. Am J Kidney Dis. 2011; 57:692-699. [PubMed: 21333426]

6. Nielsen S, Frokiaer J, Marples D, Kwon TH, Agre P, Knepper MA. Aquaporins in the kidney: from molecules to medicine. Physiol Rev. 2002; 82:205-244. [PubMed: 11773613]

7. Knepper MA, Wade JB, Terris J, Ecelbarger CA, Marples D, Mandon B, Chou CL, Kishore BK, Nielsen S. Renal aquaporins (review article). Kidney International. 1996; 49:1712-1717. [PubMed: 8743483]

8. Nielsen S, Smith BL, Christensen EI, Knepper MA, Agre P. CHIP28 water channels are localized in constitutively water-permeable segments of the nephron. Journal of Cell Biology. 1993; 120:371383. [PubMed: 7678419]

9. Maeda Y, Smith BL, Agre P, Knepper MA. Quantification of Aquaporin-CHIP water channel protein in microdissected renal tubules by fluorescence-based ELISA. Journal of Clinical Investigation. 1995; 95:422-428. [PubMed: 7529263]

10. Knepper, MA.; Valtin, H.; Sands, JM. Renal actions of vasopressin. In: Fray, JCS., editor. Handbook of Physiology: The Endocrine System (Section 7). New York: Oxford; 2000. p. 496-529.

11. Fushimi K, Uchida S, Hara Y, Hirata Y, Marumo F, Sasaki S. Cloning and expression of apical membrane water channel of rat kidney collecting tubule. Nature. 1993; 361:549-552. [PubMed: 8429910]

12. Ecelbarger CA, Terris J, Frindt G, Echevarria M, Marples D, Nielsen S, Knepper MA. Aquaporin-3 water channel localization and regulation in rat kidney. American Journal of Physiology: Renal Physiology. 1995; 269:F663-F672.

13. Terris J, Ecelbarger CA, Marples D, Knepper MA, Nielsen S. Distribution of aquaporin-4 water channel expression within rat kidney. American Journal of Physiology: Renal Physiology. 1995; 269:F775-F785. 
14. van V I, Wolfswinkel J, van d I, Mol JA, Rijnberk A, Kooistra HS. Urinary aquaporin-2 excretion in dogs: a marker for collecting duct responsiveness to vasopressin. Domest Anim Endocrinol. 2004; 27:141-153. [PubMed: 15219933]

15. Bauchet AL, Masson R, Guffroy M, Slaoui M. Immunohistochemical identification of kidney nephron segments in the dog, rat, mouse, and cynomolgus monkey. Toxicol Pathol. 2011; 39:1115-1128. [PubMed: 22006284]

16. Brandt LE, Bohn AA, Charles JB, Ehrhart EJ. Localization of Canine, Feline, and Mouse Renal Membrane Proteins. Vet Pathol. 2011

17. Floyd RV, Mason SL, Proudman CJ, German AJ, Marples D, Mobasheri A. Expression and nephron segment-specific distribution of major renal aquaporins (AQP1-4) in Equus caballus, the domestic horse. Am J Physiol Regul Integr Comp Physiol. 2007; 293:R492-R503. [PubMed: 17442782]

18. Gobet R, Norregaard R, Cisek LJ, Peters CA, Nielsen S, Frokiaer J. Experimental congenital vesicoureteral reflux in sheep is associated with reduced renal expression levels of aquaporin 1 and 2. J Urol. 2008; 179:2396-2401. [PubMed: 18436250]

19. Suzuki M, Endo N, Nakano Y, Kato H, Kishiro T, Asahina K. Localization of aquaporin-2, renal morphology and urine composition in the bottlenose dolphin and the Baird's beaked whale. $\mathrm{J}$ Comp Physiol B. 2008; 178:149-156. [PubMed: 17768629]

20. Lau KK, Yang Y, Cook GA, Wyatt RJ, Nishimura H. Control of aquaporin 2 expression in collecting ducts of quail kidneys. Gen Comp Endocrinol. 2009; 160:288-294. [PubMed: 19135443]

21. Yang Y, Cui Y, Wang W, Zhang L, Bufford L, Sasaki S, Fan Z, Nishimura H. Molecular and functional characterization of a vasotocin-sensitive aquaporin water channel in quail kidney. Am J Physiol Regul Integr Comp Physiol. 2004; 287:R915-R924. [PubMed: 15205186]

22. Nishimura H. Urine concentration and avian aquaporin water channels. Pflugers Arch. 2008; 456:755-768. [PubMed: 18278509]

23. Nielsen S, Chou CL, Marples D, Christensen EI, Kishore BK, Knepper MA. Vasopressin increases water permeability of kidney collecting duct by inducing translocation of aquaporin-CD water channels to plasma membrane. Proceedings of the National Academy of Sciences, USA. 1995; 92:1013-1017.

24. Nielsen S, DiGiovanni SR, Christensen EI, Knepper MA, Harris HW. Cellular and subcellular immunolocalization of vasopressin-regulated water channel in rat kidney. Proceedings of the National Academy of Sciences, USA. 1993; 90:11663-11667.

25. Hayashi M, Sasaki S, Tsuganezawa H, Monkawa T, Kitajima W, Konishi K, Fushimi K, Marumo F, Saruta T. Expression and distribution of aquaporin of collecting duct are regulated by V $\{-2\}$ receptor in rat kidney. Journal of Clinical Investigation. 1994; 94:1778-1783. [PubMed: 7525648]

26. DiGiovanni SR, Nielsen S, Christensen EI, Knepper MA. Regulation of collecting duct water channel expression by vasopressin in Brattleboro rat. Proceedings of the National Academy of Sciences, USA. 1994; 91:8984-8988.

27. Saito T, Ishikawa S, Sasaki S, Higashiyama M, Nagasaka S, Fujita N, Fushimi K, Marumo F. Lack of vasopressin-independent upregulation of AQP-2 gene expression in homozygous Brattleboro rats. Am J Physiol. 1999; 277:R427-R433. [PubMed: 10444549]

28. Kishore BK, Terris JM, Knepper MA. Quantitation of aquaporin-2 abundance in microdissected collecting ducts: Axial distribution and control by AVP. American Journal of Physiology. 1996; 271:F62-F70. [PubMed: 8760244]

29. Nedvetsky PI, Tabor V, Tamma G, Beulshausen S, Skroblin P, Kirschner A, Mutig K, Boltzen M, Petrucci O, Vossenkamper A, Wiesner B, Bachmann S, Rosenthal W, Klussmann E. Reciprocal regulation of aquaporin-2 abundance and degradation by protein kinase A and p38-MAP kinase. $\mathrm{J}$ Am Soc Nephrol. 2010; 21:1645-1656. [PubMed: 20724536]

30. Pisitkun T, Jacob V, Schleicher SM, Chou CL, Yu MJ, Knepper MA. Akt and ERK1/2 pathways are components of the vasopressin signaling network in rat native IMCD. Am J Physiol Renal Physiol. 2008; 295:F1030-F1043. [PubMed: 18667481] 
31. Yu MJ, Miller RL, Uawithya P, Rinschen MM, Khositseth S, Braucht DW, Chou CL, Pisitkun T, Nelson RD, Knepper MA. Systems-level analysis of cell-specific AQP2 gene expression in renal collecting duct. Proc Natl Acad Sci U S A. 2009; 106:2441-2446. [PubMed: 19190182]

32. Kanno K, Sasaki S, Hirata Y, Ishikawa S, Fushimi K, Nakanishi S, Bichet DG, Marumo F. Urinary excretion of aquaporin-2 in patients with diabetes insipidus. New England Journal of Medicine. 1995; 332:1540-1545. [PubMed: 7537863]

33. Pisitkun T, Shen RF, Knepper MA. Identification and proteomic profiling of exosomes in human urine. Proc Natl Acad Sci U S A. 2004; 101:13368-13373. [PubMed: 15326289]

34. Pisitkun T, Johnstone R, Knepper MA. Discovery of urinary biomarkers. Mol Cell Proteomics. 2006; 5:1760-1771. [PubMed: 16837576]

35. Gonzales PA, Pisitkun T, Hoffert JD, Tchapyjnikov D, Star RA, Kleta R, Wang NS, Knepper MA. Large-scale proteomics and phosphoproteomics of urinary exosomes. J Am Soc Nephrol. 2009; 20:363-379. [PubMed: 19056867]

36. Elliot S, Goldsmith P, Knepper M, Haughey M, Olson B. Urinary excretion of aquaporin-2 in humans: a potential marker of collecting duct reponsiveness to vasopressin. Journal of the American Society of Nephrology. 1996; 7:403-409. [PubMed: 8704105]

37. Deen PM, van Aubel RA, van Lieburg AF, van Os CH. Urinary content of aquaporin 1 and 2 in nephrogenic diabetes insipidus. J Am Soc Nephr. 1996; 7:836-841.

38. Saito T, Ishikawa SE, Sasaki S, Nakamura T, Rokkaku K, Kawakami A, Honda K, Marumo F, Saito T. Urinary excretion of aquaporin-2 in the diagnosis of central diabetes insipidus. Journal of Clinical Endocrinology and Metabolism. 1997; 82:1823-1827. [PubMed: 9177390]

39. Rai T, Sekine K, Kanno K, Hata K, Miura M, Mizushima A, Marumo F, Sasaki S. Urinary excretion of aquaporin-2 water channel protein in human and rat. Journal of the American Society of Nephrology. 1997; 8:1357-1362. [PubMed: 9294826]

40. van V I, Kooistra HS, Timmermans-Sprang EP, Meij BP, Rijnberk A. Vasopressin response to osmotic stimulation in 18 young dogs with polyuria and polydipsia. J Vet Intern Med. 2004; 18:800-806. [PubMed: 15638262]

41. Kamsteeg EJ, Hendriks G, Boone M, Konings IB, Oorschot V, van der SP, Klumperman J, Deen PM. Short-chain ubiquitination mediates the regulated endocytosis of the aquaporin-2 water channel. Proc Natl Acad Sci U S A. 2006; 103:18344-18349. [PubMed: 17101973]

42. Sandoval P, Slentz D, Pisitkun T, Y M-J, Miller RL, Hoffert J, Knepper MA. LC-MS/MS-based large-scale profiling of protein half lives in renal collecting duct cells reveals that vasopressin increases half-life of aquaporin-2 protein. FASEB J. 2011; 25:1039.37.

43. Kitamura M. Endoplasmic reticulum stress in the kidney. Clin Exp Nephrol. 2008; 12:317-325. [PubMed: 18536867]

44. Hayashi M, Sasaki S, Tsuganezawa H, Monkawa T, Kitajima W, Konishi K, Fushimi K, Marumo F, Saruta T. Role of vasopressin V2 receptor in acute regulation of aquaporin-2. Kidney Blood Press Res. 1996; 19:32-37. [PubMed: 8818115]

45. Ecelbarger CA, Nielsen S, Olson BR, Murase T, Baker EA, Knepper MA, Verbalis JG. Role of renal aquaporins in escape from vasopressin-induced antidiuresis in rat. Journal of Clinical Investigation. 1997; 99:1852-1863. [PubMed: 9109429]

46. Khositseth S, Pisitkun T, Slentz DH, Wang G, Hoffert JD, Knepper MA, Yu MJ. Quantitative protein and mRNA profiling shows selective post-transcriptional control of protein expression by vasopressin in kidney cells. Mol Cell Proteomics. 2011; 10:M110. [PubMed: 20940332]

47. Parker R, Sheth U. P bodies and the control of mRNA translation and degradation. Mol Cell. 2007; 25:635-646. [PubMed: 17349952]

48. Liu J. Control of protein synthesis and mRNA degradation by microRNAs. Curr Opin Cell Biol. 2008; 20:214-221. [PubMed: 18329869]

49. Uchida S, Sasaki S, Fushimi K, Marumo F. Isolation of human Aquaporin-CD gene. Journal of Biological Chemistry. 1994; 269:23451-23455. [PubMed: 7522228]

50. Rai T, Uchida S, Marumo F, Sasaki S. Cloning of rat and mouse aquaporin-2 gene promoters and identification of a negative cis-regulatory element. Am J Physiol. 1997; 273:F264-F273. [PubMed: 9277587] 
51. Tchapyjnikov D, Li Y, Pisitkun T, Hoffert JD, Yu MJ, Knepper MA. Proteomic profiling of nuclei from native renal inner medullary collecting duct cells using LC-MS/MS. Physiol Genomics. 2010; 40:167-183. [PubMed: 19996160]

52. Schenk LK, Bolger SJ, Luginbuhl K, Gonzales PA, Rinschen MM, Yu MJ, Hoffert JD, Pisitkun T, Knepper MA. Quantitative Proteomics Identifies Vasopressin-Responsive Nuclear Proteins in Collecting Duct Cells. J Am Soc Nephrol. 2012

53. Hozawa S, Holtzman EJ, Ausiello DA. cAMP motifs regulating transcription in the aquaporin-2 gene. American Journal of Physiology. 1996; 270:C1695-C1702. [PubMed: 8764152]

54. Matsumura Y, Uchida S, Rai T, Sasaki S, Marumo F. Transcriptional regulation of aquaporin-2 water channel gene by cAMP. Journal of the American Society of Nephrology. 1997; 8:861-867. [PubMed: 9189851]

55. Yasui M, Zelenin SM, Celsi G, Aperia A. Adenylate cyclase-coupled vasopressin receptor activates AQP2 promoter via a dual effect on CRE and AP1 elements. Am J Physiol Renal Physiol. 1997; 272:F443-F450.

56. Furuno M, Uchida S, Marumo F, Sasaki S. Repressive regulation of the aquaporin-2 gene. Am J Physiol. 1996; 271:F854-F860. [PubMed: 8898015]

57. Uchida S, Matsumura Y, Rai T, Sasaki S, Marumo F. Regulation of aquaporin-2 gene transcription by GATA-3. Biochem Biophys Res Commun. 1997; 232:65-68. [PubMed: 9125153]

58. Hasler U, Jeon US, Kim JA, Mordasini D, Kwon HM, Feraille E, Martin PY. Tonicity-responsive enhancer binding protein is an essential regulator of aquaporin-2 expression in renal collecting duct principal cells. J Am Soc Nephrol. 2006; 17:1521-1531. [PubMed: 16641150]

59. Li SZ, McDill BW, Kovach PA, Ding L, Go WY, Ho SN, Chen F. Calcineurin-NFATc signaling pathway regulates AQP2 expression in response to calcium signals and osmotic stress. Am J Physiol Cell Physiol. 2007; 292:C1606-C1616. [PubMed: 17166937]

60. Terris J, Ecelbarger CA, Nielsen S, Knepper MA. Long-term regulation of four renal aquaporins in rat. American Journal of Physiology. 1996; 271:F414-F422. [PubMed: 8770174]

61. Cha JH, Woo SK, Han KH, Kim YH, Handler JS, Kim J, Kwon HM. Hydration status affects nuclear distribution of transcription factor tonicity responsive enhancer binding protein in rat kidney. J Am Soc Nephrol. 2001; 12:2221-2230. [PubMed: 11675398]

62. Hoffert JD, Chou CL, Fenton RA, Knepper MA. Calmodulin is required for vasopressin-stimulated increase in cyclic AMP production in inner medullary collecting duct. J Biol Chem. 2005; 280:13624-13630. [PubMed: 15710610]

63. Nielsen S, Knepper MA. Vasopressin activates collecting duct urea transporters and water channels by distinct physical processes. American Journal of Physiology. 1993; 265:F204-F213. [PubMed: 8396342]

64. Wall SM, Han JS, Chou CL, Knepper MA. Kinetics of urea and water permeability activation by vasopressin in rat terminal IMCD. American Journal of Physiology. 1992; 262:F989-F998. [PubMed: 1320335]

65. Star RA, Nonoguchi H, Balaban R, Knepper MA. Calcium and cyclic adenosine monophosphate as second messengers for vasopressin in the rat inner medullary collecting duct. Journal of Clinical Investigation. 1988; 81:1879-1888. [PubMed: 2838523]

66. Yip KP. Coupling of vasopressin-induced intracellular Ca2+ mobilization and apical exocytosis in perfused rat kidney collecting duct. J Physiol. 2002; 538:891-899. [PubMed: 11826172]

67. Chou CL, Christensen BM, Frische S, Vorum H, Desai RA, Hoffert JD, de Lanerolle P, Nielsen S, Knepper MA. Non-muscle myosin II and myosin light chain kinase are downstream targets for vasopressin signaling in the renal collecting duct. J Biol Chem. 2004; 279:49026-49035. [PubMed: 15347643]

68. Hoffert JD, Pisitkun T, Wang G, Shen RF, Knepper MA. Quantitative phosphoproteomics of vasopressin-sensitive renal cells: regulation of aquaporin-2 phosphorylation at two sites. Proc Natl Acad Sci U S A. 2006; 103:7159-7164. [PubMed: 16641100]

69. Rinschen MM, Yu MJ, Wang G, Boja ES, Hoffert JD, Pisitkun T, Knepper MA. Quantitative phosphoproteomic analysis reveals vasopressin V2-receptor-dependent signaling pathways in renal collecting duct cells. Proc Natl Acad Sci U S A. 2010; 107:3882-3887. [PubMed: 20139300] 
70. Bansal AD, Hoffert JD, Pisitkun T, Hwang S, Chou CL, Boja ES, Wang G, Knepper MA. Phosphoproteomic profiling reveals vasopressin-regulated phosphorylation sites in collecting duct. J Am Soc Nephrol. 2010; 21:303-315. [PubMed: 20075062]

71. Uawithya P, Pisitkun T, Ruttenberg BE, Knepper MA. Transcriptional profiling of native inner medullary collecting duct cells from rat kidney. Physiol Genomics. 2008; 32:229-253. [PubMed: 17956998]

72. Torres VE, Bankir L, Grantham JJ. A case for water in the treatment of polycystic kidney disease. Clin J Am Soc Nephrol. 2009; 4:1140-1150. [PubMed: 19443627]

73. O'Leary CA, Mackay BM, Malik R, Edmondston JE, Robinson WF, Huxtable CR. Polycystic kidney disease in bull terriers: an autosomal dominant inherited disorder. Aust Vet J. 1999; 77:361-366. [PubMed: 10812399]

74. Eaton KA, Biller DS, DiBartola SP, Radin MJ, Wellman ML. Autosomal dominant polycystic kidney disease in Persian and Persian-cross cats. Vet Pathol. 1997; 34:117-126. [PubMed: 9066078]

75. Mutig K, Paliege A, Kahl T, Jons T, Muller-Esterl W, Bachmann S. Vasopressin V2 receptor expression along rat, mouse, and human renal epithelia with focus on TAL. Am J Physiol Renal Physiol. 2007; 293:F1166-F1177. [PubMed: 17626156]

76. Gattone VH, Wang X, Harris PC, Torres VE. Inhibition of renal cystic disease development and progression by a vasopressin V2 receptor antagonist. Nat Med. 2003; 9:1323-1326. [PubMed: 14502283]

77. Yamaguchi T, Nagao S, Wallace DP, Belibi FA, Cowley BD, Pelling JC, Grantham JJ. Cyclic AMP activates B-Raf and ERK in cyst epithelial cells from autosomal-dominant polycystic kidneys. Kidney Int. 2003; 63:1983-1994. [PubMed: 12753285]

78. Torres VE. Vasopressin antagonists in polycystic kidney disease. Semin Nephrol. 2008; 28:306317. [PubMed: 18519091]

79. Schrier RW, Ohara M, Rogachev B, Xu L, Knotek M. Aquaporin-2 water channels and vasopressin antagonists in edematous disorders. Mol Genet Metab. 1998; 65:255-263. [PubMed: 9889012]

80. Rossi TA, Ross LA. Diabetes insipidus. Compend Contin Educ Vet. 2008; 30:43-52. [PubMed: 18278747]

81. Schott HC. Water homeostasis and diabetes insipidus in horses. Vet Clin North Am Equine Pract. 2011; 27:175-195. [PubMed: 21392661]

82. Harb MF, Nelson RW, Feldman EC, Scott-Moncrieff JC, Griffey SM. Central diabetes insipidus in dogs: 20 cases (1986-1995). J Am Vet Med Assoc. 1996; 209:1884-1888. [PubMed: 8944803]

83. Authement JM, Boudrieau RJ, Kaplan PM. Transient, traumatically induced, central diabetes insipidus in a dog. J Am Vet Med Assoc. 1989; 194:683-685. [PubMed: 2925484]

84. Foley C, Bracker K, Drellich S. Hypothalamic-pituitary axis deficiency following traumatic brain injury in a dog. J Vet Emerg Crit Care (San Antonio ). 2009; 19:269-274. [PubMed: 19691512]

85. Ferguson DC, Biery DN. Diabetes insipidus and hyperadrenocorticism associated with high plasma adrenocorticotropin concentration and a hypothalamic/pituitary mass in a dog. J Am Vet Med Assoc. 1988; 193:835-839. [PubMed: 2848001]

86. Goossens MM, Rijnberk A, Mol JA, Wolfswinkel J, Voorhout G. Central diabetes insipidus in a dog with a pro-opiomelanocortin-producing pituitary tumor not causing hyperadrenocorticism. $\mathrm{J}$ Vet Intern Med. 1995; 9:361-365. [PubMed: 8531185]

87. Hanson JM, van 't HM, Voorhout G, Teske E, Kooistra HS, Meij BP. Efficacy of transsphenoidal hypophysectomy in treatment of dogs with pituitary-dependent hyperadrenocorticism. J Vet Intern Med. 2005; 19:687-694. [PubMed: 16231713]

88. Teshima T, Hara Y, Taoda T, Teramoto A, Tagawa M. Central diabetes insipidus after transsphenoidal surgery in dogs with Cushing's disease. J Vet Med Sci. 2011; 73:33-39. [PubMed: 20736519]

89. Neer TM, Reavis DU. Craniopharyngioma and associated central diabetes insipidus and hypothyroidism in a dog. J Am Vet Med Assoc. 1983; 182:519-520. [PubMed: 6833092] 
90. Nielsen L, Thompson H, Hammond GJ, Chang YP, Ramsey IK. Central diabetes insipidus associated with primary focal B cell lymphoma in a dog. Vet Rec. 2008; 162:124-126. [PubMed: 18223271]

91. Davenport DJ, Chew DJ, Johnson GC. Diabetes insipidus associated with metastatic pancreatic carcinoma in a dog. J Am Vet Med Assoc. 1986; 189:204-205. [PubMed: 3017907]

92. Post K, McNeill JR, Clark EG, Dignean MA, Olynyk GP. Congenital central diabetes insipidus in two sibling Afghan hound pups. J Am Vet Med Assoc. 1989; 194:1086-1088. [PubMed: 2708115]

93. Campbell FE, Bredhauer B. Trauma-induced central diabetes insipidus in a cat. Aust Vet J. 2008; 86:102-105. [PubMed: 18304048]

94. Aroch I, Mazaki-Tovi M, Shemesh O, Sarfaty H, Segev G. Central diabetes insipidus in five cats: clinical presentation, diagnosis and oral desmopressin therapy. J Feline Med Surg. 2005; 7:333339. [PubMed: 15927500]

95. Smith JR, Elwood CM. Traumatic partial hypopituitarism in a cat. J Small Anim Pract. 2004; 45:405-409. [PubMed: 15352410]

96. Rogers WA, Valdez H, Anderson BC, Comella C. Partial deficiency of antidiuretic hormone in a cat. J Am Vet Med Assoc. 1977; 170:545-547. [PubMed: 557470]

97. Burnie AG, Dunn JK. A case of central diabetes insipidus in the cat: diagnosis and treatment. J Small Anim Pract. 1982; 23:237-241.

98. Court MH, Watson AD. Idiopathic neurogenic diabetes insipidus in a cat. Aust Vet J. 1983; 60:245-247. [PubMed: 6639529]

99. Green RA, Farrow CS. Diabetes insipidus in a cat. J Am Vet Med Assoc. 1974; 164:524-526. [PubMed: 4813412]

100. Pittari JM. Central diabetes insipidus in a cat. Feline Pract. 2012; 24:18-21.

101. Winterbotham J, Mason KV. Congenital diabetes insipidus in a kitten. J Small Anim Pract. 1983; 24:569-573.

102. Simpson CJ, Mansfield CS, Milne ME, Hodge PJ. Central diabetes insipidus in a cat with central nervous system B cell lymphoma. J Feline Med Surg. 2011; 13:787-792. [PubMed: 21906986]

103. Breukink HJ, Van WP, Schotman AJ. Idiopathic diabetes insipidus in a Welsh pony. Equine Vet J. 1983; 15:284-287. [PubMed: 6884322]

104. Filar J, Ziolo T, Szalecki J. Diabetes insipidus in the course of encephalitis in the horse. Med Weter. 1971; 27:205-207.

105. McFarlane D. Equine pituitary pars intermedia dysfunction. Vet Clin Equine. 2011; 27:93-113.

106. Kranenburg LC, Thelen MH, Westermann CM, de Graaf-Roelfsema E, van der Kolk JH. Use of desmopressin eye drops in the treatment of equine congenital central diabetes insipidus. Vet Rec. 2010; 167:790-791. [PubMed: 21262613]

107. Braun U, Feller B, Gerber A, Ossent P. Diabetes insipidus in a Swiss Braunvieh heifer with internal hydrocephalus. Schweiz Arch Tierheilkd. 2008; 150:409-412. [PubMed: 18777727]

108. Wallace CE, Kociba GJ. Diabetes insipidus in a cow. J Am Vet Med Assoc. 1979; 175:809-811. [PubMed: 528321]

109. Thomson JR, Anderson DH, Gilmour JS. Neurogenic diabetes insipidus in a sheep. J Comp Pathol. 1986; 96:119-124. [PubMed: 3944284]

110. Houpt KA. Feeding and drinking behavior problems. Vet Clin North Am Small Anim Pract. 1991; 21:281-298. [PubMed: 2053251]

111. Mulnix JA, Rijnberk A, Hendriks HJ. Evaluation of a modified water-deprivation test for diagnosis of polyuric disorders in dogs. J Am Vet Med Assoc. 1976; 169:1327-1330. [PubMed: 1033931]

112. van VI, Kooistra HS, Sprang EP, Rijnberk A. Disturbed vasopressin release in 4 dogs with socalled primary polydipsia. J Vet Intern Med. 1999; 13:419-425. [PubMed: 10499724]

113. Grauer GF, Pitts RP. Primary polydipsia in three dogs with portosystemic shunts. J Am Anim Hosp Assoc. 1987; 23:197-200.

114. Henderson SM, Elwood CM. A potential causal association between gastrointestinal disease and primary polydipsia in three dogs. J Small Anim Pract. 2003; 44:280-284. [PubMed: 12831107] 
115. McKenzie EC. Polyuria and polydipsia in horses. Vet Clin North Am Equine Pract. 2007; 23:641-653. vii. [PubMed: 18061855]

116. Browning AP. Polydipsia and polyuria in two horses caused by psychogenic polydipsia. Equine Vet Educ. 2000; 12:175-178.

117. Buntain BJ, Coffman JR. Polyuria and polydypsia in a horse induced by psychogenic salt consumption. Equine Vet J. 1981; 13:266-268. [PubMed: 7318809]

118. Suttle, N. Mineral nutrition of livestock. 4th ed. Wallingford, UK: CABI; 2010. Sodium and chloride; p. 182-205.

119. Valtin H. "Drink at least eight glasses of water a day" Really? Is there scientific evidence for "8×8"? Am J Physiol Regul Integr Comp Physiol. 2002; 283:R993-R1004. [PubMed: 12376390]

120. De Wardener HE, Herxheimer A. The effect of a high water intake on the kidney's ability to concentrate the urine in man. J Phyisiol Lond. 1957; 139:42-52.

121. Harbaugh C, Knepper MA. Do you have a drinking problem? Running Times. 2007; 9:14-17.

122. Bichet DG. Hereditary polyuric disorders: new concepts and differential diagnosis 6 . Semin Nephrol. 2006; 26:224-233. [PubMed: 16713495]

123. Luzius H, Jans DA, Grunbaum EG, Moritz A, Rascher W, Fahrenholz F. A low affinity vasopressin V2-receptor in inherited nephrogenic diabetes insipidus. J Recept Res. 1992; 12:351-368. [PubMed: 1387165]

124. Schott HC, Bayly WM, Reed SM, Brobst DF. Nephrogenic diabetes insipidus in sibling colts. J Vet Intern Med. 1993; 7:68-72. [PubMed: 8501698]

125. Deen PM, Marr N, Kamsteeg EJ, van Balkom BW. Nephrogenic diabetes insipidus. Curr Opin Nephrol Hypertens. 2000; 9:591-595. [PubMed: 11128419]

126. Brummermann M, Braun EJ. Renal response of roosters with diabetes insipidus to infusions of arginine vasotocin. Am J Physiol. 1995; 269:R57-R63. [PubMed: 7631903]

127. Minvielle F, Grossmann R, Gourichon D. Development and performances of a Japanese quail line homozygous for the diabetes insipidus (di) mutation. Poult Sci. 2007; 86:249-254. [PubMed: 17234837]

128. Marples D, Christensen S, Christensen EI, Ottosen PD, Nielsen S. Lithium-induced downregulation of aquaporin-2 water channel expression in rat kidney medulla. J Clin Invest. 1995; 95:1838-1845. [PubMed: 7535800]

129. Frokiaer J, Marples D, Knepper MA, Nielsen S. Bilateral ureteral obstruction downregulates expression of vasopressin-sensitive AQP-2 water channel in rat kidney. Am J Physiol. 1996; 270:F657-F668. [PubMed: 8967344]

130. Marples D, Frokiaer J, Dorup J, Knepper MA, Nielsen S. Hypokalemia-induced downregulation of aquaporin-2 water channel expression in rat kidney medulla and cortex. Journal of Clinical Investigation. 1996; 97:1960-1968. [PubMed: 8621781]

131. Frokiaer J, Christensen BM, Marples D, Djurhuus JC, Jensen UB, Knepper MA, Nielsen S. Downregulation of aquaporin-2 parallels changes in renal water excretion in unilateral ureteral obstruction. Am J Physiol. 1997; 273:F213-F223. [PubMed: 9277582]

132. Li C, Wang W, Kwon TH, Isikay L, Wen JG, Marples D, Djurhuus JC, Stockwell A, Knepper MA, Nielsen S, Frokiaer J. Downregulation of AQP1-2, and-3 after ureteral obstruction is associated with a long-term urine-concentrating defect. Am J Physiol Renal Physiol. 2001; 281:F163-F171. [PubMed: 11399657]

133. Li C, Wang W, Knepper MA, Nielsen S, Frokiaer J. Downregulation of renal aquaporins in response to unilateral ureteral obstruction. Am J Physiol Renal Physiol. 2003; 284:F1066-F1079. [PubMed: 12517734]

134. Kim SW, Cho SH, Oh BS, Yeum CH, Choi KC, Ahn KY, Lee J. Diminished renal expression of aquaporin water channels in rats with experimental bilateral ureteral obstruction. J Am Soc Nephrol. 2001; 12:2019-2028. [PubMed: 11562400]

135. Jensen AM, Li C, Praetorius HA, Norregaard R, Frische S, Knepper MA, Nielsen S, Frokiaer J. Angiotensin II mediates downregulation of aquaporin water channels and key renal sodium transporters in response to urinary tract obstruction. Am J Physiol Renal Physiol. 2006; 291:F1021-F1032. [PubMed: 16757730] 
136. Norregaard R, Jensen BL, Li C, Wang W, Knepper MA, Nielsen S, Frokiaer J. COX-2 inhibition prevents downregulation of key renal water and sodium transport proteins in response to bilateral ureteral obstruction. Am J Physiol Renal Physiol. 2005; 289:F322-F333. [PubMed: 15840770]

137. Norregaard R, Jensen BL, Topcu SO, Diget M, Schweer H, Knepper MA, Nielsen S, Frokiaer J. $\mathrm{COX}-2$ activity transiently contributes to increased water and $\mathrm{NaCl}$ excretion in the polyuric phase after release of ureteral obstruction. Am J Physiol Renal Physiol. 2007; 292:F1322-F1333. [PubMed: 17229676]

138. Stone KA. Lithium-induced nephrogenic diabetes insipidus. J Am Board Fam Pract. 1999; 12:4347. [PubMed: 10050642]

139. Abrams-Ogg AC. The use of lithium carbonate to prevent lomustine-induced myelosuppression in dogs: a pilot study. Can J Vet Res. 2011; 75:73-76. [PubMed: 21461200]

140. Davies NL. Lithium toxicity in two dogs. J S Afr Vet Assoc. 1991; 62:140-142. [PubMed: 1770485]

141. Wen H, Frokiaer J, Kwon TH, Nielsen S. Urinary excretion of aquaporin-2 in rat is mediated by a vasopressin-dependent apical pathway. Journal of the American Society of Nephrology. 1999; 10:1416-1429. [PubMed: 10405197]

142. Laursen UH, Pihakaski-Maunsbach K, Kwon TH, Ostergaard JE, Nielsen S, Maunsbach AB. Changes of rat kidney AQP2 and Na,K-ATPase mRNA expression in lithium-induced nephrogenic diabetes insipidus. Nephron Exp Nephrol. 2004; 97:e1-e16. [PubMed: 15153756]

143. Christensen S, Kusano E, Yusufi AN, Murayama N, Dousa TP. Pathogenesis of nephrogenic diabetes insipidus due to chronic administration of lithium in rats. J Clin Invest. 1985; 75:18691879. [PubMed: 2989335]

144. Li Y, Shaw S, Kamsteeg EJ, Vandewalle A, Deen PM. Development of lithium-induced nephrogenic diabetes insipidus is dissociated from adenylyl cyclase activity. J Am Soc Nephrol. 2006; 17:1063-1072. [PubMed: 16495377]

145. Sands JM, Naruse M, Baum M, Jo I, Hebert SC, Brown EM, Harris HW. Apical extracellular calcium/polyvalent cation-sensing receptor regulates vasopressin-elicited water permeability in rat kidney inner medullary collecting duct. J Clin Invest. 1997; 99:1399-1405. [PubMed: 9077550]

146. Bustamante M, Hasler U, Leroy V, de SS, Dimitrov M, Mordasini D, Rousselot M, Martin PY, Feraille E. Calcium-sensing receptor attenuates AVP-induced aquaporin-2 expression via a calmodulin-dependent mechanism. J Am Soc Nephrol. 2008; 19:109-116. [PubMed: 18032798]

147. Rao R, Patel S, Hao C, Woodgett J, Harris R. GSK3beta mediates renal response to vasopressin by modulating adenylate cyclase activity. J Am Soc Nephrol. 2010; 21:428-437. [PubMed: 20056751]

148. Nielsen J, Hoffert JD, Knepper MA, Agre P, Nielsen S, Fenton RA. Proteomic analysis of lithium-induced nephrogenic diabetes insipidus: mechanisms for aquaporin 2 down-regulation and cellular proliferation. Proc Natl Acad Sci U S A. 2008; 105:3634-3639. [PubMed: 18296634]

149. Berl T, Linas SL, Aisenbrey GA, Anderson RJ. On the mechanism of polyuria in potassium depletion. The role of polydipsia. J Clin Invest. 1977; 60:620-625. [PubMed: 893666]

150. HOLLANDER W Jr, WINTERS RW, WILLIAMS TF, BRADLEY J, Oliver J, Welt LG. Defect in the renal tubular reabsorption of water associated with potassium depletion in rats. Am $\mathrm{J}$ Physiol. 1957; 189:557-563. [PubMed: 13458384]

151. Manitius A, LEVITIN H, BECK D, Epstein FH. On the mechanism of impairment of renal concentrating ability in potassium deficiency. J Clin Invest. 1960; 39:684-692. [PubMed: 14420649]

152. Rutecki GW, Cox JW, Robertson GW, Francisco LL, Ferris TF. Urinary concentrating ability and antidiuretic hormone responsiveness in the potassium-depleted dog. J Lab Clin Med. 1982; 100:53-60. [PubMed: 6953158]

153. Marples D, Frokiaer J, Dorup J, Knepper MA, Nielsen S. Hypokalemia-induced downregulation of aquaporin-2 water channel expression in rat kidney medulla and cortex. J Clin Invest. 1996; 97:1960-1968. [PubMed: 8621781] 
154. Amlal H, Krane CM, Chen Q, Soleimani M. Early polyuria and urinary concentrating defect in potassium deprivation. Am J Physiol Renal Physiol. 2000; 279:F655-F663. [PubMed: 10997915]

155. Pretzer SD. Clinical presentation of canine pyometra and mucometra: a review. Theriogenology. 2008; 70:359-363. [PubMed: 18513791]

156. Kenney KJ, Matthiesen DT, Brown NO, Bradley RL. Pyometra in cats: 183 cases (1979-1984). J Am Vet Med Assoc. 1987; 191:1130-1132. [PubMed: 3693035]

157. Heiene R, van VI, Moe L, Molmen GS, Larsen NH, Kooistra HS. Vasopressin secretion in response to osmotic stimulation and effects of desmopressin on urinary concentrating capacity in dogs with pyometra. Am J Vet Res. 2004; 65:404-408. [PubMed: 15077680]

158. Scheim A. Renal function in dogs with pyometra. 2. Concentrating and diluting ability. Acta Vet Scand. 1963; 4:293-306.

159. Maddens B, Heiene R, Smets P, Svensson M, Aresu L, van der LJ, Daminet S, Meyer E. Evaluation of kidney injury in dogs with pyometra based on proteinuria, renal histomorphology, and urinary biomarkers. J Vet Intern Med. 2011; 25:1075-1083. [PubMed: 21848947]

160. Grinevich V, Knepper MA, Verbalis J, Reyes I, Aguilera G. Acute endotoxemia in rats induces down-regulation of V2 vasopressin receptors and aquaporin-2 content in the kidney medulla. Kidney Int. 2004; 65:54-62. [PubMed: 14675036]

161. Hasler U, Leroy V, Jeon US, Bouley R, Dimitrov M, Kim JA, Brown D, Kwon HM, Martin PY, Feraille E. NF-kappaB Modulates aquaporin-2 transcription in renal collecting duct principal cells. J Biol Chem. 2008; 283:28095-28105. [PubMed: 18703515]

162. Hocherl K, Schmidt C, Kurt B, Bucher M. Inhibition of NF-kappaB ameliorates sepsis-induced downregulation of aquaporin-2/V2 receptor expression and acute renal failure in vivo. Am $\mathrm{J}$ Physiol Renal Physiol. 2010; 298:F196-F204. [PubMed: 19828675]

163. Stone EA, Littman MP, Robertson JL, Bovee KC. Renal dysfunction in dogs with pyometra. J Am Vet Med Assoc. 1988; 193:457-464. [PubMed: 3170321]

164. Shiel RE, Pinilla M, Mooney CT. Syndrome of inappropriate antidiuretic hormone secretion associated with congenital hydrocephalus in a dog. J Am Anim Hosp Assoc. 2009; 45:249-252. [PubMed: 19723849]

165. Brofman PJ, Knostman KA, DiBartola SP. Granulomatous amebic meningoencephalitis causing the syndrome of inappropriate secretion of antidiuretic hormone in a dog. J Vet Intern Med. 2003; 17:230-234. [PubMed: 12683626]

166. Breitschwerdt EB, Root CR. Inappropriate secretion of antidiuretic hormone in a dog. J Am Vet Med Assoc. 1979; 175:181-186. [PubMed: 500439]

167. Houston DM, Allen DG, Kruth SA, Pook H, Spinato MT, Keough L. Syndrome of inappropriate antidiuretic hormone secretion in a dog. Can Vet J. 1989; 30:423-425. [PubMed: 17423323]

168. Rijnberk A, Biewenga WJ, Mol JA. Inappropriate vasopressin secretion in two dogs. Acta Endocrinol (Copenh). 1988; 117:59-64. [PubMed: 3381626]

169. Fleeman LM, Irwin PJ, Phillips PA, West J. Effects of an oral vasopressin receptor antagonist (OPC-31260) in a dog with syndrome of inappropriate secretion of antidiuretic hormone. Aust Vet J. 2000; 78:825-830. [PubMed: 11194468]

170. Cameron K, Gallagher A. Syndrome of inappropriate antidiuretic hormone secretion in a cat. J Am Anim Hosp Assoc. 2010; 46:425-432. [PubMed: 21041336]

171. Grant IA, Karnik K, Jandrey KE. Toxicities and salvage therapy following overdose of vinblastine in a cat. J Small Anim Pract. 2010; 51:127-131. [PubMed: 20137000]

172. Fujita N, Ishikawa SE, Sasaki S, Fujisawa G, Fushimi K, Marumo F, Saito T. Role of water channel AQP-CD in water retention in SIADH and cirrhotic rats. American Journal of Physiology. 1995; 269:F926-F931. [PubMed: 8594889]

173. Saito T, Higashiyama M, Nagasaka S, Sasaki S, Saito T, Ishikawa SE. Role of aquaporin-2 gene expression in hyponatremic rats with chronic vasopressin-induced antidiuresis. Kidney Int. 2001; 60:1266-1276. [PubMed: 11576341]

174. Ecelbarger CA, Chou CL, Lee AJ, DiGiovanni SR, Verbalis JG, Knepper MA. Escape from vasopressin-induced antidiuresis: Role of vasopressin resistance of the collecting duct. American Journal of Physiology. 1998; 274:F1161-F1166. [PubMed: 9841509] 


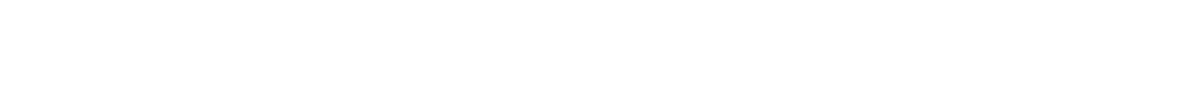

\section{Exosome Release}

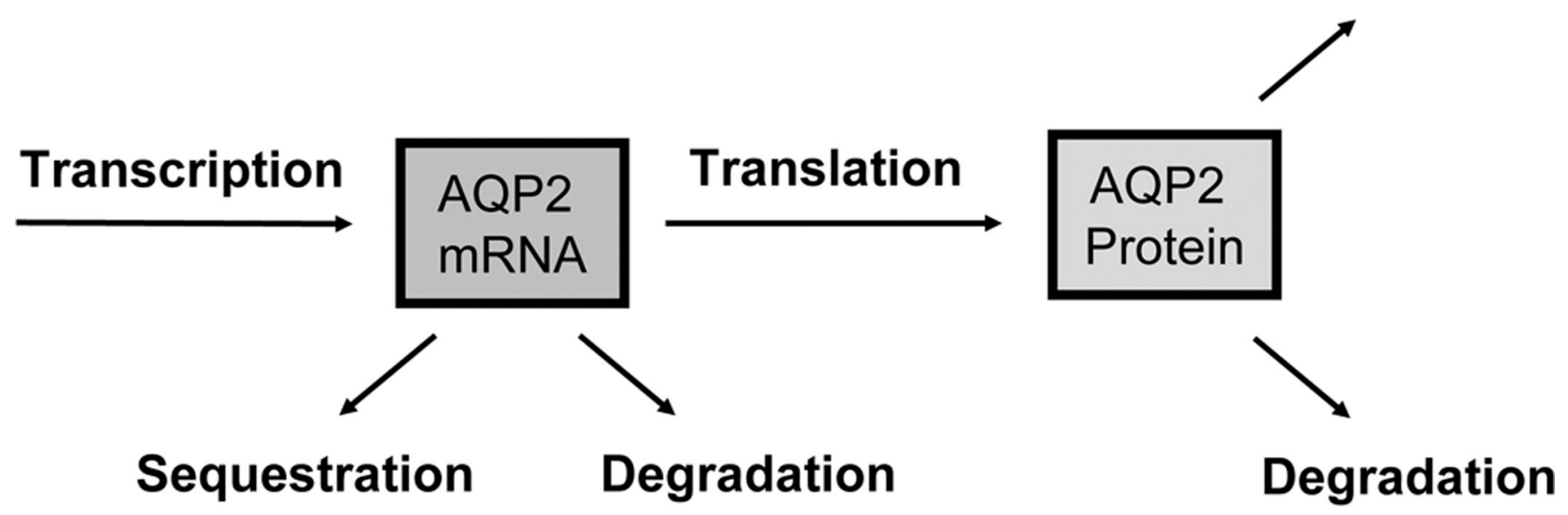

Figure 1.

Processes that determine AQP2 levels in collecting duct cells. See text for explanation. 